\title{
Summer habitat selection by ringed seals (Pusa hispida) in the drifting sea ice of the northern Barents Sea
}

\author{
Karen Lone ${ }^{(i)}$, Charmain D. Hamilton, Jon Aars, Christian Lydersen \& Kit M. Kovacs \\ Norwegian Polar Institute, Fram Centre, Tromsø, Norway
}

\begin{abstract}
Ringed seals are a central component of the Arctic ecosystem; they have a circumpolar distribution and are both important predators of lower trophic animals (invertebrates and fishes) and prey for polar bears and coastal human populations. They depend on sea ice for reproduction, moulting and resting, and they consume significant amounts of ice-associated prey. The population of ringed seals in Svalbard, Norway, uses both coastal and offshore habitats, the latter being important during seasonal migrations undertaken by some animals, mostly juveniles. This study examined habitat preferences of 18 satellite-tracked ringed seals (mostly young animals, but also a few adults) during late summer/autumn migrations to the drift ice in the northern Barents Sea. Resource selection functions showed that ringed seals preferred being close to the $50 \%$ sea-ice concentration threshold; a $120 \mathrm{~km}$ increase in the distance to the $50 \%$ sea-ice concentration threshold halved the probability of selection of a given area. In addition, higher sea-ice concentrations (80-100\%) were between 1.4 and 2.2 times as likely to be selected as lower sea-ice concentrations or open water. Ringed seals use the marginal ice zone of the Barents Sea during summer/ autumn. This offshore habitat has shifted northward during recent decades, which is likely causing negative effects on ringed seals by increasing the energetic cost of offshore migrations.
\end{abstract}

To access the supplementary material, please visit the article landing page

\section{Introduction}

Climate warming is having widespread consequences for individuals, species and ecosystem processes across the globe (Scheffers et al. 2016). The change has been largest in the Arctic, where warming has already led to significant reductions in the extent, thickness and age of sea ice (Stroeve et al. 2012; IPCC 2014). The Barents Sea region, which includes the Svalbard Archipelago, has experienced the most dramatic change in duration and extent of sea ice across the circumpolar Arctic (Laidre et al. 2015). The summer sea-ice concentration has declined by $3.4 \%$ per decade, and the ice-free season (when sea-ice cover is less than a threshold value) lengthened by 34 days per decade between 1979 and 2013 (Stern \& Laidre 2016). This prompts a need to know more about the habitat use and requirements of the region's ice-associated species. The ringed seal (Pusa hispida) is an ice-associated endemic Arctic seal species

\section{Keywords:}

Arctic; Svalbard; climate change; marginal ice zone; RSF; sea ice-associated marine mammals

\section{Correspondence}

Karen Lone, Norwegian Polar Institute, Fram Centre, PO Box 6606 Langnes, NO-9296 Tromsø, Norway. E-mail: karen. lone@gmail.com

\section{Abbreviations \\ AIC: Akaike information criterion; ASI-SSMI: Special Sensor Microwavellmager and IImager Sounder data processed by the ARTIST Sea Ice algorithm; MIZ: marginal ice zone; RSF: resource selection function.}

that uses sea ice as a platform for reproduction, moulting and resting (Gjertz \& Lydersen 1986; Reeves 1998). Although ringed seals are opportunistic with regard to what they eat (Yurkowski et al. 2016), much of their diet is ice-associated fish and invertebrates (Reeves 1998; Labansen et al. 2007). Most ringed seals give birth on land-fast sea ice in fjords during the spring.

Ringed seals are facing challenges in their coastal habitats in Svalbard, Norway (Hamilton et al. 2016). Land-fast sea ice in Svalbard is currently in decline: it is present for fewer days and it covers smaller areas in recent decades compared to the past (Muckenhuber et al. 2016), likely already affecting recruitment. Successful reproduction depends on having a stable ice platform with sufficient snow cover for the construction of lairs in which a mother can leave her pup when she leaves to forage during the six-week nursing period (Smith \& Stirling 1975; Lydersen \& Gjertz 1986). In contrast, habitat requirements of ringed seals are less specific outside the breeding 
season, and habitat choices in summer and autumn may to a larger degree be decided by foraging opportunities as this is an intensive fattening period (Kelly et al. 2010). Many subadult ringed seals in Svalbard, as well as some few adults, migrate offshore during summer/autumn each year, using the drifting sea-ice habitat for foraging and resting for a period up to several months, between July and November (Freitas, Kovacs, Ims, Fedak et al. 2008; Hamilton et al. 2015; Hamilton et al. 2017).Other seals may even stay in these offshore areas year-round, as individuals have been documented breeding in the pack ice in the Barents Sea (Wiig et al. 1999).

Sea ice is important beyond the breeding season, as a substrate for hauling out to rest (conserving energy). While ringed seals in Svalbard have shown some flexibility in selection of summer haul-out substrates, now coming onto land in some coastal areas where sea ice is no longer available (Lydersen et al. 2017), this option is not available to animals when they are offshore. The offshore drifting sea ice is also declining and retreating northward, making seasonal migrations longer and hence more energetically costly. Earlier studies have found that ringed seal space use in offshore habitats depends strongly on sea-ice concentration. Freitas and co-workers modelled the probability of leaving an area and found that the seals preferred intermediate sea-ice concentrations $(40-80 \%)$ compared to areas with very high sea-ice concentrations (80-100\%) (Freitas, Kovacs, Ims, Fedak et al. 2008). Hamilton et al. (2017) compared habitat characteristics along real and simulated ringed seal trajectories, using a generalized additive model, and found that the relative preference peaked at $80 \%$ sea-ice concentration.

The aim of this study was to gain further insight into the space use and habitat requirements of ringed seals in the drifting sea-ice habitat in the Barents Sea via use of step-based RSFs. These models permit inferences about habitat preferences and predictions of habitat suitability across landscapes (Boyce \& McDonald 1999). Such knowledge will be essential for management and conservation planning for ice-affiliated marine mammal populations as the region becomes ice-free for longer periods of the year and faces increased anthropogenic impacts during the seals' offshore migration period in the summer/autumn (e.g., ship traffic and interest in offshore oil and gas development).

\section{Methods}

\section{Capture and instrumentation}

Sixty ringed seals were captured in Svalbard during two tagging periods (July-August of 2002-03 and 2010-12) and equipped with Satellite Relay Data Loggers (SMRU Instrumentation). The seals were captured using drift nets set from shore. Immediately after capture, they were placed in individual restraining nets. Body mass was measured (Salter spring scales; precision $\pm 0.5 \mathrm{~kg}$ ) and sex was determined before the Satellite Relay Data Loggers were glued to the hair on the back mid-dorsally using quick-setting epoxy. The weight of the devices was on average $1.1 \%$ of the seals' body mass (range: 0.4 to $2.0 \%$ ). The age of the animals was not determined. It could be inferred, based on body mass and ringed seal growth curves (Lydersen \& Gjertz 1987; Krafft et al. 2006), that the sample included both juvenile and adult ringed seals. The growth curves by Krafft et al. (2006) show an asymptotic adult body mass of $69 \mathrm{~kg}$ for both sexes but also large individual variation, which makes conclusive statements about age or maturity at the individual level difficult. All animal-handling protocols were approved by the Governor of Svalbard and the Norwegian Animal Research Authority.

Eighteen of the 60 seals tagged undertook extensive offshore excursions, mainly to the Barents Sea and the Arctic Ocean Basin north of the Barents Sea (Table 1). Fourteen of the animals that went offshore were female and four were males. Only one animal was very large $(90 \mathrm{~kg}$ ) and obviously an adult, while many of the seals were small and therefore presumably juveniles ( 11 of the 18 seals weighed between 30 and $40 \mathrm{~kg}$ ). The remaining six seals had weights between 50 and $60 \mathrm{~kg}$ and were likely sexually mature.

\section{Study area}

Detailed patterns of the movement ecology of the 18 individuals that undertook offshore excursions to the Barents Sea, in relation to their ice environment(s), were the subject of this study. See Hamilton et al. (2016) for a broader analysis of space use using data from all 60 tagged seals. The Barents Sea is a shallow shelf sea in the European Arctic, which encompasses the Svalbard (Norway) and Franz Josef Land (Russia) archipelagos (Fig. 1). Having retreated from its former year-round position over the continental shelf of the Barents Sea (average depth $230 \mathrm{~m}$ ), the MIZ is now located over the deep Arctic Ocean Basin (typical depth in excess of $3000 \mathrm{~m}$ ) during the period of minimum sea-ice extent in the late summer and autumn. The study area therefore extended northward to $86^{\circ} \mathrm{N}$, including deep-water areas with ice cover (Fig. 1).

\section{Location data}

Ringed seal locations were estimated by the Argos satellite system (CLS 2016). To remove possible location errors, 
Table 1 Details regarding the ringed seals tagged in Svalbard that were tracked offshore in 2002, 2003, 2010, 2011 and 2012. Tagging location and date, sex, body mass at capture and details of its offshore trip(s), and number of daily time steps from the MIZ that each seal contributed to the data set underlying the RSF model.

\begin{tabular}{|c|c|c|c|c|c|c|c|}
\hline Seal & Sex & Mass (kg) & Tagging date & Tagging location & $\begin{array}{c}\text { Dates of } \\
\text { offshore trip(s) }\end{array}$ & $\begin{array}{l}\text { Track end } \\
\text { or return }\end{array}$ & $\begin{array}{l}\text { Number of daily } \\
\text { steps in model }\end{array}$ \\
\hline F31-02 & $\mathrm{F}$ & 31 & $21 / 07 / 2002$ & Snaddodden & 22 Jul-29 Aug & return & 24 \\
\hline F33-02 & $\mathrm{F}$ & 33 & 21/07/2002 & Snaddodden & 26 Jul-6 Sep & return & 32 \\
\hline F36-02 & $\mathrm{F}$ & 36 & 21/07/2002 & Snaddodden & 29 Jul-2 Sep & return & 24 \\
\hline F37-02 & $\mathrm{F}$ & 37 & 20/07/2002 & Snaddodden & 23 Aug-21 Nov & return & 79 \\
\hline F57-02 & $\mathrm{F}$ & 57 & 19/07/2002 & Snaddodden & 1 Aug-1 Sep & return & 21 \\
\hline F59-02 & $\mathrm{F}$ & 59 & 21/07/2002 & Snaddodden & $\begin{array}{l}1 \text { Aug-25 Aug } \\
15 \text { Sep-30 Sep }\end{array}$ & $\begin{array}{l}\text { return; } \\
\text { track end }\end{array}$ & 35 \\
\hline M50-02 & M & 50 & 19/07/2002 & Snaddodden & $23 \mathrm{Jul}-20 \mathrm{Oct}$ & track end & 60 \\
\hline F34-03 & $\mathrm{F}$ & 34 & 19/07/2003 & Snaddodden & $\begin{array}{l}24 \text { Jul-11 Aug } \\
18 \text { Aug-8 Sep }\end{array}$ & $\begin{array}{l}\text { return; } \\
\text { return }\end{array}$ & 27 \\
\hline F37-03 & $\mathrm{F}$ & 37 & 22/07/2003 & Snaddodden & 7 Aug-18 Sep & return & 36 \\
\hline F34-10 & $\mathrm{F}$ & 34 & 03/08/2010 & Kløverbladbukta & 5 Aug- 5 Oct & return & 47 \\
\hline F40-10 & $\mathrm{F}$ & 40 & 25/07/2010 & Utvika & 2 Aug-30 Sep & return & 56 \\
\hline M36-10 & M & 36 & 26/07/2010 & Utvika & $31 \mathrm{Jul}-12 \mathrm{Nov}$ & return & 36 \\
\hline F52-10 & $\mathrm{F}$ & 52 & 03/08/2010 & Kløverbladbukta & 17 Aug-9 Sep & return & 19 \\
\hline F60-10 & $\mathrm{F}$ & 60 & 29/07/2010 & Depotlaguna & $\begin{array}{l}31 \text { Jul-2 Sep } \\
3 \text { Oct-19 oct }\end{array}$ & $\begin{array}{l}\text { return; } \\
\text { return }\end{array}$ & 21 \\
\hline M62-10 & M & 62 & 01/08/2010 & Kløverbladbukta & 15 Aug-4 Sep & return & 19 \\
\hline M90-11 & M & 90 & 03/08/2011 & Kongsfjorden & 6 Aug-1 Sep & return & 23 \\
\hline F35-12 & $\mathrm{F}$ & 35 & 30/07/2012 & Kløverbladbukta & 12 Aug-27 Aug & return & 12 \\
\hline F40-12 & $\mathrm{F}$ & 40 & 01/08/2012 & Kløverbladbukta & 13 Aug-29 Sep & return & 35 \\
\hline
\end{tabular}

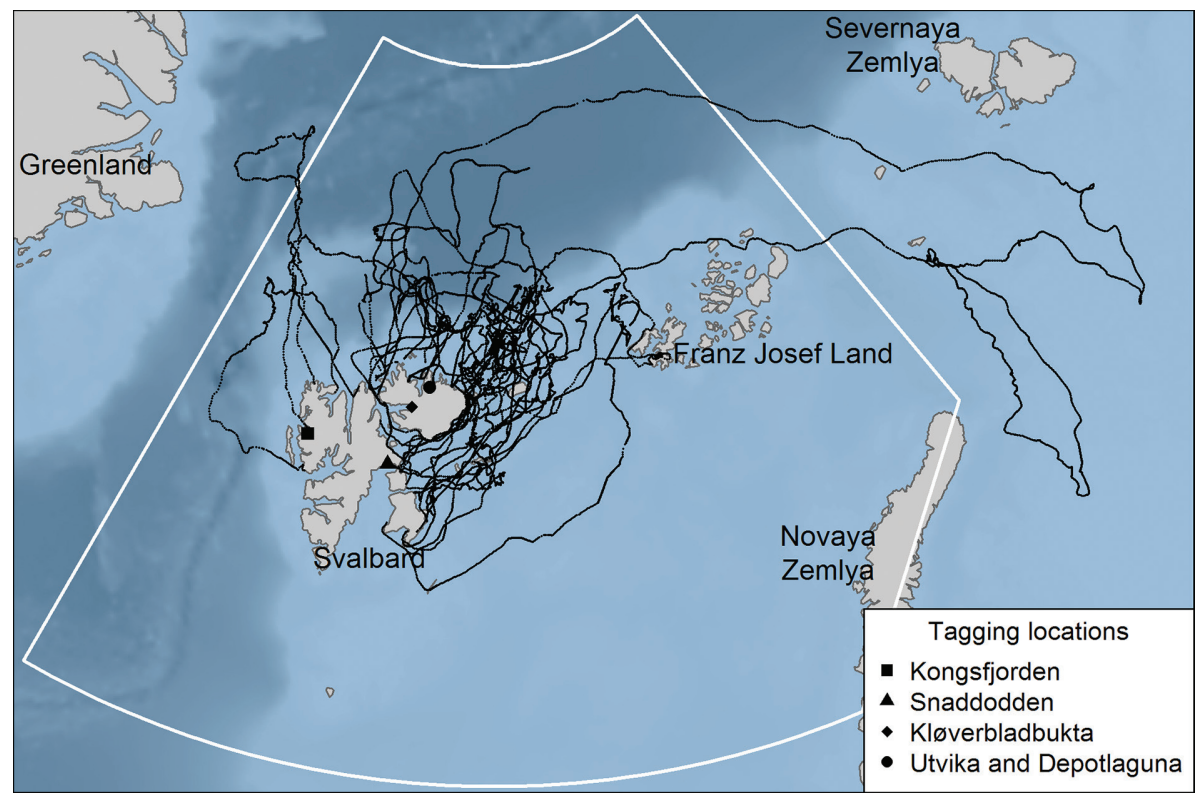

Fig. 1 Study area showing the offshore tracks from 18 ringed seals and the sites where the seals were tagged in the Svalbard Archipelago. Background relief shows the bathymetry of the region (with deeper water being darker shades of blue). The white line delimits the study area.

the seals' tracks were first filtered using the speed-distance-angle filter with default settings in R 3.2.2 (Freitas, Lydersen et al. 2008; R Core Team 2015). Any obviously erroneous locations (i.e., locations far inland) were then manually removed using ArcMap10 10.0 (ESRI 2011, ArcGIS Desktop: Release 10, Environmental Systems 
Research Institute). All subsequent analyses were conducted in R 3.2.2 (R Core Team 2015). Positions from each seal were filtered using the continuous time correlated random walk model with a stopping model incorporated to account for time spent hauled out (see Johnson et al. 2008 for methodology). Hourly locations were extracted from these models for time periods when the seals were offshore, starting from when a seal left the coast of Svalbard with a directed, offshore movement until it returned or transmission terminated.

\section{Habitat data}

Daily maps of sea-ice concentration at $12.5 \mathrm{~km}$ resolution were downloaded from the Integrated Climate Data Center at the University of Hamburg (http://icdc.zmaw.de/; Kaleschke et al. 2001; Spreen et al. 2008). This product is based on the ASI-SSMI data processed by the French Research Institute for Exploitation of the Sea (Brest, http://wwz.ifremer.fr/), further processed and provided as a five-day median-filtered and gap-filled product by the Integrated Climate Data Center. In calculations of distance to various sea-ice concentration thresholds, it was assumed that there was $100 \%$ sea-ice cover in the area surrounding the North Pole (north of the study area), where there is an absence of data. The extent of contiguous drifting sea ice in the Barents Sea was delineated using thresholds of 15, 50 and 75\% sea-ice concentration. Based on these lines, new raster maps were calculated in which the value of each pixel was the shortest distance to each threshold value. Ocean depth estimates were obtained from the International Bathymetric Chart of the Arctic Ocean (Jakobsson et al. 2012) and rescaled from the original $500 \mathrm{~m}$ resolution to match the 12.5 $\mathrm{km}$ resolution of the sea-ice data. A distance to land raster, with the same resolution, was calculated using open source vector maps of coastlines downloaded from http:// geodata.npolar.no/ for Svalbard's islands and from http:// www.naturalearthdata.com/ for all other landmasses.

\section{Resource selection modelling}

Step-based RSFs were developed to estimate the relative probability of use of available habitat in the drifting sea ice. The data were restricted to time spent in the MIZ of the Barents Sea. Transits from Svalbard to the drift ice were identified manually by overlaying the data on ice charts. Starting with the departure from land (Svalbard), data were excluded until a daily step started at a location with (some) sea ice in the MIZ. Return transits to land were identified in the same manner, and data were excluded backwards in time until the last step ended at a location with sea ice. The steps considered were 24-hr intervals (i.e., daily); these blocks were analysed as a step selection function using a buffer approach to define a set of available locations to pair with the used location from the same step. Sampling alternative steps from the empirical distribution of angles and distances, although preferred in many contexts, was not used because the daily distances moved were often short, and the method was not very useful when applied to habitat data with a $12.5 \mathrm{~km}$ resolution. A second reason the buffer approach was preferred in this study was because it accounted for areas that were actually within reach of the seals when moving in the dynamic sea-ice habitat. Available habitat was considered as all $12.5 \mathrm{~km}$ pixels within a radius corresponding to the 97.5th percentile speed of the 24-hr time steps of all offshore movement of all of the ringed seals in this data set $(84.0 \mathrm{~km})$, to capture the area they were estimated to be able to reach within the step interval. In a few instances, the length of the actual step taken by the seal exceeded this radius, and the radius defining the available habitat was increased (up to $108 \mathrm{~km}$ ) for those steps to include the location that was actually used. For each step, the pixel containing the used location was matched with all of the unused locations (pixels) that the seal could have reached, in a paired analysis. The modelling extended to the use of sea ice areas and nearby areas of open water, but pixels without sea ice $(<1 \%)$ that were farther than one day's travel $(84.0 \mathrm{~km})$ from the $15 \%$ sea-ice threshold were excluded from the data set. If the pixel containing the used location itself was farther away from sea ice than this, the entire time step was excluded from the data set. Thus, the ice-covered areas and areas within $84.0 \mathrm{~km}$ of it together defined the domain of inference for the models.

The exponential RSF was estimated by modelling the used versus available pixels as a conditional logistic regression using the "survival" package (Therneau 2015) in $\mathrm{R}$ 3.2.2 ( $\mathrm{R}$ Core Team 2015). The conditionality in the model was specified by using a unique identity assigned to each used position and the set of available pixels associated with it as "strata" when specifying the model. Because the correlation between multiple observations from a seal can cause underestimation of the variance in the model, seal identity was included as a "cluster" term to compute a robust variance for the models. Models were constructed with habitat variables known or likely to be important to the seals and that had a large impact on model performance. Sex and body mass were not used as predictors because the sample was highly skewed with respect to these factors (Table 1). Sea-ice concentration was included as a categorical variable with five levels $(0-15 \%, 15-40 \%, 40-60 \%, 60-80 \%$ and $80-100 \%)$ to give a large degree of flexibility in the relative selection along the gradient from zero to complete sea-ice cover. Distance to the $15 \%, 50 \%$ or the $75 \%$ sea-ice 
concentration thresholds were considered as the second predictor variable. Distance to $50 \%$ sea-ice concentration was used in the final model because its inclusion had the largest improvement in AIC values (Supplementary Table S1). Distance to land and whether the location was on (or off) the continental shelf (defined by the $600 \mathrm{~m}$ isobath) were not included in the final model because their inclusion did not improve the AIC values (Supplementary Table S1). The exponential RSF modelled a response coded " 1 " for a used pixel and " 0 " for available pixels according to the following formula: Response $\sim$ ice. conc + dist_ice. $50+$ strata $($ ID-day $)+$ cluster(ID) .

\section{Predictive RSF maps}

Daily RSF maps were predicted pixel by pixel, using the estimated model and daily sea-ice raster data layers. The predictions were restricted to areas with valid input data, excluding landmasses, open water farther than $84.0 \mathrm{~km}$ from the $15 \%$ sea-ice contour and anything outside the defined study area boundaries. Predicted RSF values were

Table 2 Seasonal distribution of the data used to model ringed seal RSFs in the Barents Sea, using daily (24-hr) steps from 18 tracked individuals.

\begin{tabular}{lcc}
\hline & Number of steps & Percentage of all steps \\
\hline July & 12 & 2.0 \\
August & 335 & 55.3 \\
September & 156 & 25.7 \\
October & 70 & 11.6 \\
November & 33 & 5.4 \\
Total & 606 & 100 \\
\hline
\end{tabular}

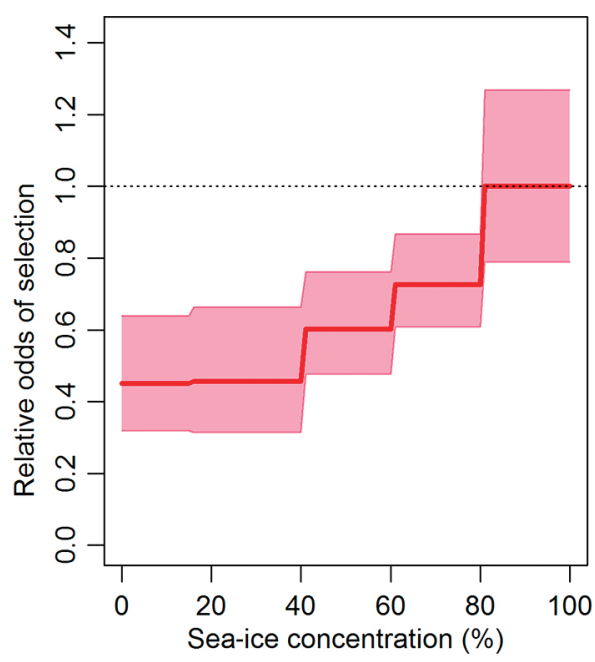

standardized to the interval $0-1$ by simple division by the maximum RSF value theoretically generated by the model, allowing comparison of relative probability of use within and across dates.

\section{Results}

The offshore tracking data from the 18 ringed seals that travelled to the drifting ice edge $(N=18$, Fig. 1) resulted in a data set that included 849 daily steps. Of these, 152 (18\%) were transit steps that were excluded from the modelling. Additionally, an unusual detour (66 time steps; 8\%) made by one seal (seal M36-10 in Table 1) east into the Kara Sea (Fig. 1) was excluded. Restricting the remaining steps to areas with sea ice, or within $84.0 \mathrm{~km}$ of it, excluded an additional 25 steps $(3 \%)$. The data set used in the modelling therefore consisted of 606 daily steps, with each seal contributing an average of $34 \pm 17$ (standard deviation) steps (range: 12-79). All of the seals made their offshore excursions in the late summer and autumn (Tables 1 and 2). The RSF models were based on data that spanned the period 26 July through 21 November, with most of the data collected in August and September (55.3 and 25.7\% of all steps, respectively; Table 2).

The model for the seals' habitat use in the drifting sea ice shows that they preferred to be close to the $50 \%$ sea-ice concentration threshold (Fig. 2, Table 3). The likelihood of selection decreased to half in areas $120 \mathrm{~km}$ from the $50 \%$ sea-ice concentration and further to one-tenth at $380 \mathrm{~km}$ distance, just within the largest value represented in the data set $(400.2 \mathrm{~km})$. Sea-ice concentration in the area itself also had some influence; selection of

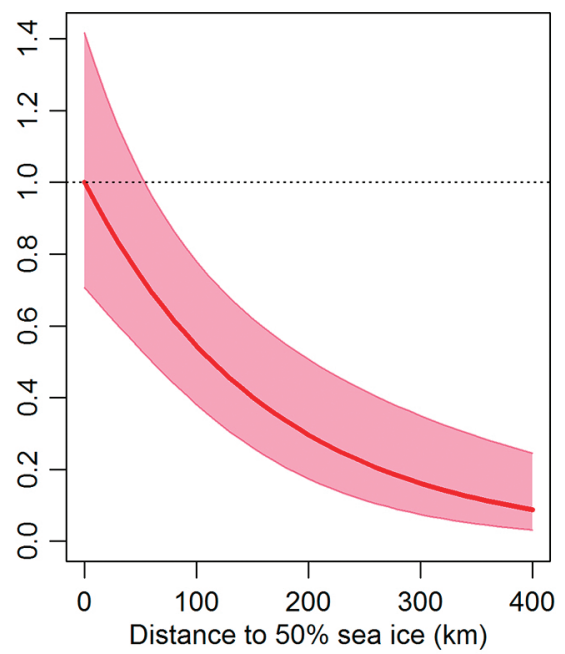

Fig. 2 Ringed seal offshore foraging habitat selection in terms of the relative odds of selecting habitat according to sea-ice concentration and distance to the $50 \%$ sea-ice concentration threshold (up to $400 \mathrm{~km}$, the largest value present in the data set). 
the $80-100 \%$ sea-ice concentration was approximately 2.2 times as likely as sea-ice concentrations between 0 and $40 \%, 1.7$ times as likely as sea-ice concentrations between 40 and $60 \%$ and about 1.4 times as likely as seaice concentrations between 60 and $80 \%$ (Fig. 2, Table 3).

The sample size limits the value of detailed comparisons between the two tagging periods (2002-03 and 2010-12), or between males and females, but fitting the best model to each of the temporal or sex subsets of the data separately did not show any major differences in

Table 3 Model coefficients for the RSF for ringed seal offshore foraging habitat, estimated with a conditional logistic model including sea-ice concentration (factor variable, ice concentration 0-15\% as reference level), and distance to the $50 \%$ sea-ice concentration threshold.

\begin{tabular}{lccccc}
\hline & $\beta$ & $\exp (\beta)$ & $\mathrm{SE}$ & $\mathrm{Z}$ & $p$ \\
\hline Ice concentration 15-40\% & 0.013 & 1.01 & 0.3 & 0.05 & 0.96 \\
Ice concentration 40-60\% & 0.289 & 1.34 & 0.2 & 1.19 & 0.23 \\
Ice concentration 60-80\% & 0.476 & 1.61 & 0.2 & 2.08 & 0.04 \\
Ice concentration 80-100\% & 0.795 & 2.21 & 0.2 & 3.46 & 0.001 \\
Distance to 50\% sea ice & -0.006 & 0.99 & 0.001 & -4.33 & $<0.0001$ \\
\hline
\end{tabular}

the pattern between the two time periods, or between the sexes (Supplementary Fig. S1). The predictive model for ringed seal space use shows selection for the MIZ as a very general feature and a northward shift of the habitat concurrent with the reduction in regional sea-ice cover (Fig. 3).

\section{Discussion}

A short distance to the $50 \%$ sea-ice threshold was the main habitat characteristic selected by the ringed seals tracked during their offshore excursions in the Barents Sea in the late summer and autumn. The attraction to the sea-ice edge translates into a clear pattern in the predicted preferred habitat offshore and, presumably, also to the distribution of ringed seals in these offshore areas at this time of year. The drifting sea ice of the Barents Sea moves around with wind and ocean currents, and the seals select areas that keep them close to or within the MIZ. Seals that remained coastal throughout the year were not included in this analysis (41 animals; one seal whose tag sent only three days of data was also excluded).
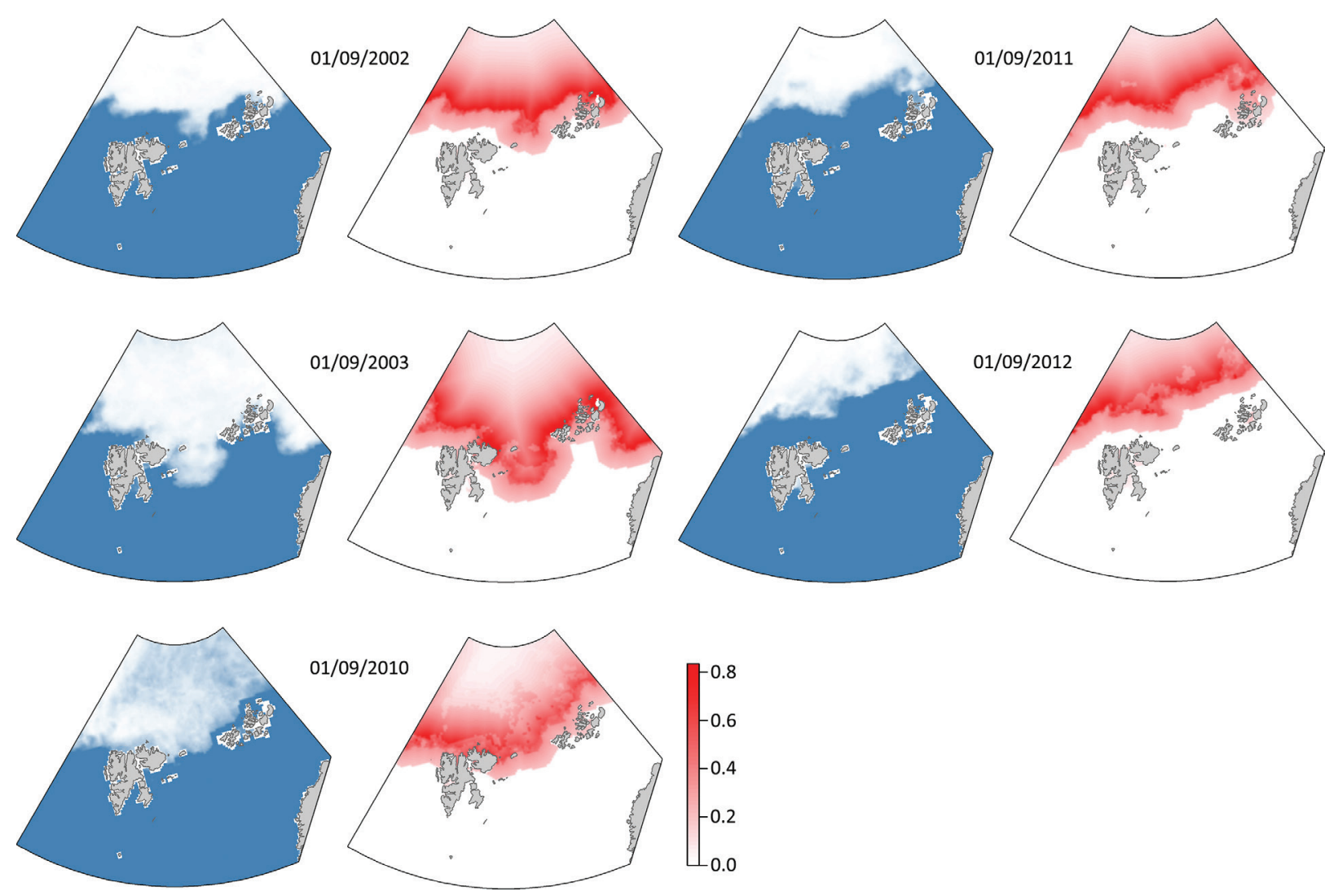

Fig. 3 Maps of sea-ice conditions and the associated predicted RSF values (i.e., relative likelihood of selection) of the offshore foraging habitat for ringed seals across the study area on 1 September in the five years of this study. 
These coastally resident animals showed a strong preference for glacier fronts, which are highly productive areas (see Hamilton et al. 2016 for details). The seals migrating offshore were likely selecting the MIZ for the same reason. Physical and biological processes at the ice edge make it a high productivity area (Sakshaug \& Walsh 2000; Barber et al. 2015), supporting high prey availability that is advantageous for foraging (Stirling 1997). An assemblage of top predators tend to use ice-edge habitats in the Arctic, including seabirds, seals and polar bears (Hamilton et al. 2017). While the RSF model showed that seals were attracted to the $50 \%$ sea-ice concentrations (from either side), it also showed a preference for the highest sea-ice concentration $(80-100 \%)$. The overall pattern is that seals select areas close to the sea-ice edge, preferring areas in the MIZ with a lot of ice cover. Moving deeper into the ice would mean entering (or moving further into) the Arctic Ocean Basin, where prey availability is likely to be lower. Arctic shelf areas have higher productivity than deep-sea areas (Arrigo \& van Dijken 2015), though elevated productivity will likely follow the MIZ northward to some extent. Using areas far into the ice may also entail a risk of becoming trapped on or under the sea ice if strong southern winds compact the ice, closing the leads that seals and other marine mammals use for breathing.

The selection of sea-ice concentration itself is relatively weak in the model presented herein, compared to that identified by other ringed seal habitat selection model studies. At the scale of daily time steps used in this study, $80-100 \%$ sea-ice concentrations were found to be weakly favoured over intermediate sea-ice concentrations $(40-60 \%)$. Selection is always determined with reference to availability, and selection of a rare habitat type stands out more easily than selection of a common habitat type. Not all sea-ice concentrations were equally available in this study (Supplementary Table S2). However, the category that was selected most strongly (80-100\% sea-ice concentration) was typically abundant in the set of available locations; the median proportion of available locations (according to step level) was 56\%. Intermediate sea-ice concentrations (40-60\% and 60-80\%) were less abundant, with median availabilities of $7 \%$ and $19 \%$, respectively. Other studies based on subsets of the same data analysed here showed strong preference for intermediate sea-ice concentrations in other modelling frameworks (Freitas, Kovacs, Ims, Fedak et al. 2008; Hamilton et al. 2017). In a study by Hamilton et al. (2017), available locations were generated by simulating entire tracks, likely having a lower relative availability of intermediate sea ice (compared to availability of $100 \%$ sea ice and $0 \%$ sea ice) and thereby identifying a stronger selection on sea-ice concentration on this scale. The daily time steps used in this study captured the importance of the transition zone from low to high sea-ice concentration through the emerging pattern of attraction to a sea-ice concentration threshold.

The RSF model predicts that optimal offshore foraging habitat for ringed seals is within the MIZ. Making broader inferences about ringed seal distribution per se would rely on the assumption that all habitat units are equally likely to be encountered, which is probably not true. This assumption is necessary for the RSF to be informative about the probability of a unit being used (Lele et al. 2013), a metric that again is approximately proportional to animal density if the probabilities are low. Although the main pattern is that the ringed seals tend to stay in the MIZ, the seals also use and cross open water on their migratory trajectories. Our prediction area (area of inference for our models) is restricted to the areas with sea ice and adjacent areas of open water within a day's swim $(84.0 \mathrm{~km})$ of a pixel with at least $15 \%$ sea ice. Ringed seals will be found outside the area of inference of the models when they are in transit between Svalbard and the MIZ. Their migratory paths were very markedly directional as they went north-eastward to north-north-eastward away from land and toward the ice, often involving continuous swimming until the animal reached the MIZ (Freitas, Kovacs, Ims, Fedak et al. 2008). After reaching the offshore drift ice, the ringed seals' tracks sometimes included periods when they moved out into open water, even beyond the $84 \mathrm{~km}$ buffer zone, without the trip being the return migration. However, these trips were generally short, only a few days in duration, with the exception of the trip made by M36-10 into the Kara Sea.

\section{Seasonal migrants}

Of the 60 seals captured along the coast in summer, about one-third subsequently migrated north, presumably for foraging. Animals that took offshore migrations were predominantly, but not exclusively, young animals. Additional tagging effort on the west coast of Svalbard in 2016 and 2017 resulted in tracks from 15 presumably adult ringed seals (all weighing $53 \mathrm{~kg}$ or more), and none of these animals travelled offshore (Lydersen $\&$ Kovacs, unpubl. data). It seems likely that migration by juveniles may be a result of competition for resources at glacier fronts in Svalbard fjords (Lydersen et al. 2014; Hamilton et al. 2016), a highly preferred habitat but very spatially restricted compared with the MIZ. Migrating animals tracked coastally in Svalbard before and after their excursions did not use the areas around glacier fronts as intensively as resident individuals did, indicating a possible exclusion (Hamilton et al. 2016). For subdominant individuals, offshore areas may offer a profitable alternative. Another possible explanation for the tendency for spatial 
segregation could be ontogenetic differences in foraging and preferred prey that motivate juveniles to undertake offshore excursions more commonly than adults. Juveniles and adults may have different abilities to exploit the resources at glacier fronts and in the MIZ. Such differences could for example be related to increased diving capacity, prey handling ability or optimal prey size with age. However, ringed seal diet has been shown to be broad and opportunistic, and diet differences between juveniles and adults have not been shown in Svalbard (Gjertz \& Lydersen 1986). A recent study of ringed seal diet across the Canadian Arctic found ontogenetic differences in some regions. However, these were a result of adults specializing on certain prey while juveniles remained generalists (Yurkowski et al. 2016). It seems unlikely that the high productivity and attractiveness of glacier front habitats is less exploitable by generalist juveniles than (potentially) specialized adults, as these areas support a wide range of predators, ranging in size from small seabirds to whales (Descamps et al. 2017).

\section{Climate change perspectives}

Recent sea-ice declines have resulted in a northward shift of habitat for ringed seals in the Barents Sea. The offshore drifting sea-ice habitat is becoming more distant from islands in Svalbard for longer parts of the year, requiring longer transits over open water. This is already influencing polar bear space use and denning habitat choices in the region (Andersen et al. 2012; Aars et al. 2017). Calculations by Freitas, Kovacs, Ims and \& Lydersen (2008) suggested that migrating to the MIZ is energetically feasible for ringed seals if it is within $600-700 \mathrm{~km}$ of Svalbard. The offshore habitat may be used in the post-breeding period not only by ringed seals breeding or born in Svalbard, but also by ringed seals from Franz Josef Land or Novaya Zemlya and seals breeding or born in the pack ice of the Barents Sea itself (Wiig et al. 1999). It is not clear at present whether ringed seals from all these other areas are part of the same population or whether they form distinct populations. In terms of the offshore breeding areas and the ringed seals using them, relatively little is known about them beyond documentation of their existence across the Arctic (Smith \& Stirling 1975; Finley et al. 1983; Reeves 1998).

In addition to affecting travel distance, the northward shift of the MIZ also creates a new oceanographic context for the ice-covered areas, as the ice is no longer located over the continental shelf, but rather it occurs in late summer only over the Arctic Ocean Basin. A study of ringed seal behaviour in the time periods before and after the shift in sea-ice regime (2006 turning point) shows higher foraging effort in the second time period, with seals swimming more, showing less area-restricted search behaviour, diving longer, making shorter surface intervals, resting less on sea ice and diving less directly beneath the sea ice (Hamilton et al. 2015). Arctic sea ice is also becoming thinner and younger (Maslanik et al. 2011), and multiyear ice with typically large assemblages of sympagic fauna is being replaced by annual ice that has less developed sympagic food webs and lower potential prey biomass for seals (Barber et al. 2015). Polar cod (Boreogadus saida), which is a central prey species for ringed seals in the Barents Region (Labansen et al. 2007), has a widespread distribution in the pack ice habitat (David et al. 2016; Kohlbach et al. 2017). It is unknown to what extent the reduction in seasonal ice cover and multiyear ice will disrupt the presence of polar cod and other ice-associated fauna in offshore habitats. Polar cod recruitment may be affected because sea ice is both a spawning habitat and an important habitat for young age classes, as it gives some protection from predation. Together with higher temperatures, which will worsen conditions for polar cod, changing ice conditions will result in decreased density and distribution of this fish species in the Barents Sea (Eriksen et al. 2015).

This study has demonstrated the importance of the MIZ for ringed seals and that they track the moving MIZ by staying close to or by moving towards the $50 \%$ seaice concentration. The knowledge and predictive models developed herein should be useful for management and conservation planning in the Barents Sea, even as the physical environmental context in this region continues to change under climate warming.

\section{Acknowledgements}

The authors thank Magnus Andersen, Lars Boehme, Heinrich Eggenfellner, Mike Fedak, Carla Freitas, Nils Christian Ravnaas Heen, Hans Lund, Benjamin Merkel and Bobben Severinsen for assistance in the field.

\section{Disclosure statement}

No potential conflict of interest was reported by the authors.

\section{Funding}

This work was supported by the Norwegian Polar Institute's Centre for Ice, Climate and Ecosystems, the Norwegian Research Council MARE programme (Seals, Bears and Ice, project no. 150323/720), VISTA (project no. 6162) and Statoil. 


\section{References}

Aars J., Marques T.A., Lone K., Andersen M., Wiig Ø., Bardalen Fløystad I.M., Hagen S.B. \& Buckland S.T. 2017. The number and distribution of polar bears in the western Barents Sea. Polar Research 36, article no. 1457880, http:// dx.doi.org/10.1080/17518369.2018.1457880.

Andersen M., Derocher A.E., Wiig O. \& Aars J. 2012. Polar bear (Ursus maritimus) maternity den distribution in Svalbard, Norway. Polar Biology 35, 499-508, http://dx.doi. org/10.1007/s00300-011-1094-y.

Arrigo K.R. \& van Dijken G.L. 2015. Continued increases in Arctic Ocean primary production. Progress in Oceanography 136 (S1), 60-70, http://dx.doi.org/10.1016/j.pocean. 2015.05.002.

Barber D.G., Hop H., Mundy C.J., Else B., Dmitrenko I.A., Tremblay J.-E., Ehn J.K., Assmy P., Daase M. \& Candlish L.M. 2015. Selected physical, biological and biogeochemical implications of a rapidly changing Arctic marginal ice zone. Progress in Oceanography 139(S1), 122-150, http://dx. doi.org/10.1016/j.pocean.2015.09.003.

Boyce M.S. \& McDonald L.L. 1999. Relating populations to habitats using resource selection functions. Trends in Ecology $\theta$ Evolution 14, 268-272, http://dx.doi.org/10.1016/ S0169-5347(99)01593-1.

CLS (Collecte Localisation Satellites) 2016. Argos user's manual: worldwide tracking and environmental monitoring by satellite. Ramonville Saint-Agne, France: Collecte Localisation Satellites.

David C., Lange B., Krumpen T., Schaafsma F., van Franeker J.A. \& Flores H. 2016. Under-ice distribution of polar cod Boreogadus saida in the central Arctic Ocean and their association with sea-ice habitat properties. Polar Biology 39(S1), 981-994, http://dx.doi.org/10.1007/ s00300-015-1774-0.

Descamps S., Aars J., Fuglei E., Kovacs K.M., Lydersen C., Pavlova O., Pedersen Å.Ø., Ravolainen V. \& Strøm H. 2017. Climate change impacts on wildlife in a High Arctic archipelago-Svalbard, Norway. Global Change Biology 23, 490-502, http://dx.doi.org/10.1111/gcb.13381.

Eriksen E., Ingvaldsen R., Nedreaas K. \& Prozorkevich D. 2015. The effect of recent warming on polar cod and beaked redfish juveniles in the Barents Sea. Regional Studies in Marine Science 2, 105-112, http://dx.doi.org/10.1016/j. rsma.2015.09.001.

Finley K., Miller G., Davis R. \& Koski W. 1983. A distinctive large breeding population of ringed seals (Phoca hispida) inhabiting the Baffin Bay pack ice. Arctic 36, 162-173.

Freitas C., Kovacs K.M., Ims R.A., Fedak M.A. \& Lydersen C. 2008. Ringed seal post-moulting movement tactics and habitat selection. Oecologia 155, 193-204, http://dx.doi. org/10.1007/s00442-007-0894-9.

Freitas C., Kovacs K.M., Ims R.A. \& Lydersen C. 2008. Predicting habitat use by ringed seals (Phoca hispida) in a warming Arctic. Ecological Modelling 217, 19-32, http://dx. doi.org/10.1016/j.ecolmodel.2008.05.014.

Freitas C., Lydersen C., Fedak M.A. \& Kovacs K.M. 2008. A simple new algorithm to filter marine mammal Argos locations. Marine Mammal Science 24, 315-325, http://dx. doi.org/10.1111/j.1748-7692.2007.00180.x.

Gjertz I. \& Lydersen C. 1986. Polar bear predation on ringed seals in the fast-ice of Hornsund, Svalbard. Polar Research 4, 65-68, http://dx.doi.org/10.1111/j.1751-8369.1986. tb00520.x.

Hamilton C.D., Kovacs K.M., Ims R.A., Aars J., Strøm H. \& Lydersen C. 2017. Spatial overlap among an Arctic predator, prey and scavenger in the marginal ice zone. Marine Ecology Progress Series 573, 45-59, http://dx.doi.org/10.3354/ meps 12184.

Hamilton C.D., Lydersen C., Ims R.A. \& Kovacs K.M. 2015. Predictions replaced by facts: a keystone species' behavioural responses to declining Arctic sea-ice. Biology Letters 11, article no. 20150803, http://dx.doi.org/10.1098/ rsbl.2015.0803.

Hamilton C.D., Lydersen C., Ims R.A. \& Kovacs K.M. 2016. Coastal habitat use by ringed seals Pusa hispida following a regional sea-ice collapse: importance of glacial refugia in a changing Arctic. Marine Ecology Progress Series 545, 261-277, http://dx.doi.org/10.3354/meps11598.

IPCC (Intergovernmental Panel on Climate Change) 2014. Climate change 2014: synthesis report. Contribution of Working Groups I, II and III to the fifth assessment report of the Intergovernmental Panel on Climate Change. Core Writing Team, R.K. Pachauri \& L.A. Meyer (eds.). Geneva: Intergovernmental Panel on Climate Change.

Jakobsson M., Mayer L., Coakley B., Dowdeswell J.A., Forbes S., Fridman B., Hodnesdal H., Noormets R., Pedersen R., Rebesco M., Schenke H.W., Zarayskaya Y., Accettella D., Armstrong A., Anderson R.M., Bienhoff P., Camerlenghi A., Church I., Edwards M., Gardner J.V., Hall J.K., Hell B., Hestvik O., Kristoffersen Y., Marcussen C., Mohammad R., Mosher D., Nghiem S.V., Pedrosa M.T., Travaglini P.G. \& Weatherall P. 2012. The International Bathymetric Chart of the Arctic Ocean (IBCAO) version 3.0. Geophysical Research Letters 39, L12609, http://dx.doi. org/10.1029/2012GL052219.

Johnson D.S., London J.M., Lea M.-A. \& Durban J.W. 2008. Continuous-time correlated random walk model for animal telemetry data. Ecology 89, 1208-1215, http://dx.doi. org/10.1890/07-1032.1.

Kaleschke L., Lupkes C., Vihma T., Haarpaintner J., Bochert A., Hartmann J. \& Heygster G. 2001. SSM/I sea ice remote sensing for mesoscale ocean-atmosphere interaction analysis. Canadian Journal of Remote Sensing 27, 526-537, http:// dx.doi.org/10.1080/07038992.2001.10854892.

Kelly B.P., Badajos O.H., Kunnasranta M., Moran J.R., Martinez-Bakker M., Wartzok D. \& Boveng P. 2010. Seasonal home ranges and fidelity to breeding sites among ringed seals. Polar Biology 33, 1095-1109, http://dx.doi.org/ 10.1007/s00300-010-0796-x.

Kohlbach D., Schaafsma F.L., Graeve M., Lebreton B., Lange B.A., David C., Vortkamp M. \& Flores H. 2017. Strong linkage of polar cod (Boreogadus saida) to sea ice algaeproduced carbon: evidence from stomach content, fatty acid and stable isotope analyses. Progress in Oceanography 152, 62-74, http://dx.doi.org/10.1016/j.pocean.2017.02.003. 
Krafft B.A., Kovacs K.M., Frie A.K., Haug T. \& Lydersen C. 2006. Growth and population parameters of ringed seals (Pusa hispida) from Svalbard, Norway, 2002-2004. ICES Journal of Marine Science 63, 1136-1144, http://dx.doi. org/10.1016/j.icesjms.2006.04.001.

Labansen A.L., Lydersen C., Haug T. \& Kovacs K.M. 2007. Spring diet of ringed seals (Phoca hispida) from northwestern Spitsbergen, Norway. ICES Journal of Marine Science 64, 1246-1256, http://dx.doi.org/10.1093/icesjms/fsm090.

Laidre K.L., Stern H., Kovacs K.M., Lowry L., Moore S.E., Regehr E.V., Ferguson S.H., Wiig Ø., Boveng P. \& Angliss R.P. 2015. Arctic marine mammal population status, sea ice habitat loss, and conservation recommendations for the 21 st century. Conservation Biology 29, 724-737, http://dx. doi.org/10.1111/cobi.12474.

Lele S.R., Merrill E.H., Keim J. \& Boyce M.S. 2013. Selection, use, choice and occupancy: clarifying concepts in resource selection studies. Journal of Animal Ecology 82, 1183-1191, http://dx.doi.org/10.1111/1365-2656.12141.

Lydersen C., Assmy P., Falk-Petersen S., Kohler J., Kovacs K.M., Reigstad M., Steen H., Strøm H., Sundfjord A. \& Varpe Ø. 2014. The importance of tidewater glaciers for marine mammals and seabirds in Svalbard, Norway. Journal of Marine Systems, 452-471, http://dx.doi.org/10.1016/j.jmarsys.2013.09.006.

Lydersen C. \& Gjertz I. 1986. Studies of the ringed seal (Phoca hispida Schreber 1775) in its breeding habitat in Kongsfjorden, Svalbard. Polar Research 4, 57-63, http://dx.doi. org/10.3402/polar.v4il.6920.

Lydersen C. \& Gjertz I. 1987. Population parameters of ringed seals (Phoca hispida Schreber, 1775) in the Svalbard area. Canadian Journal of Zoology 65, 1021-1027, http://dx.doi. org/10.1139/z87-162.

Lydersen C., Vaquie-Garcia J., Lydersen E., Christensen G.N. \& Kovacs K.M. 2017. Novel terrestrial haul-out behaviour by ringed seals (Pusa hispida) in Svalbard, in association with harbour seals (Phocavitulina). Polar Research 35, article no. 1374124, http://dx.doi.org/10.1080/17518369.2017.1 374124.

Maslanik J., Stroeve J., Fowler C. \& Emery W. 2011. Distribution and trends in Arctic sea ice age through spring 2011. Geophysical Research Letters 38, article no. L13502, http://dx.doi.org/10.1029/2011 GL047735.

Muckenhuber S., Nilsen F., Korosov A. \& Sandven S. 2016. Sea ice cover in Isfjorden and Hornsund, Svalbard (2000-2014) from remote sensing data. The Cryosphere 10, 149-158, http://dx.doi.org/10.5194/tc-10-149-2016.
R Core Team 2015. R: a language and environment for statistical computing. Vienna: R Foundation for Statistical Computing.

Reeves R.R. 1998. Distribution, abundance and biology of ringed seals (Phoca hispida): an overview. NAMMCO Scientific Publications 1, 9-45.

Sakshaug E. \& Walsh J. 2000. Marine biology: biomass, productivity distributions and their variability in the Barents and Bering Seas. In M. Nuttall \& V. Callaghan (eds.): The Arctic: environment, people, policy. Pp. 163-196. Amsterdam: Harwood Academic Publishers.

Scheffers B.R., De Meester L., Bridge T.C., Hoffmann A.A., Pandolfi J.M., Corlett R.T., Butchart S.H., Pearce-Kelly P., Kovacs K.M. \& Dudgeon D. 2016. The broad footprint of climate change from genes to biomes to people. Science 354, aaf7671, http://dx.doi.org/10.1126/science.aaf7671.

Smith T.G. \& Stirling I. 1975. The breeding habitat of the ringed seal (Phoca hispida). The birth lair and associated structures. Canadian Journal of Zoology 53, 1297-1305.

Spreen G., Kaleschke L. \& Heygster G. 2008. Sea ice remote sensing using AMSR-E 89-GHz channels. Journal of Geophysical Research-Oceans 113, C02S03, http://dx.doi. org/10.1029/2005JC003384.

Stern H.L. \& Laidre K.L. 2016. Sea-ice indicators of polar bear habitat. The Cryosphere 10, 2027-2041, http://dx.doi. org/10.5194/tc-10-2027-2016.

Stirling I. 1997. The importance of polynyas, ice edges, and leads to marine mammals and birds. Journal of Marine Systems 10, 9-21, http://dx.doi.org/10.1016/ S0924-7963(96)00054-1.

Stroeve J.C., Kattsov V., Barrett A., Serreze M., Pavlova T., Holland M. \& Meier W.N. 2012. Trends in Arctic sea ice extent from CMIP5, CMIP3 and observations. Geophysical Research Letters 39, L16502, http://dx.doi. org/10.1029/2012GL052676.

Therneau T. 2015. A package for survival analysis in S. $\mathrm{R}$ package version 2.38. https://CRAN.R-project.org/ package $=$ survival.

Wiig Ø., Derocher A.E. \& Belikov S.E. 1999. Ringed seal (Phoca hispida) breeding in the drifting pack ice of the Barents Sea. Marine Mammal Science 15, 595-598, http:// dx.doi.org/10.1111/j.1748-7692.1999.tb00828.x.

Yurkowski D.J., Ferguson S.H., Semeniuk C.A.D., Brown T.M., Muir D.C.G. \& Fisk A.T. 2016. Spatial and temporal variation of an ice-adapted predator's feeding ecology in a changing Arctic marine ecosystem. Oecologia 180, 631-644, http://dx.doi.org/10.1007/s00442-015-3384-5. 